\title{
Incorporating bazedoxifene/conjugated estrogens into the current paradigm of menopausal therapy
}

\author{
This article was published in the following Dove Press journal: \\ International Journal of Women's Health \\ 27 March 2012 \\ Number of times this article has been viewed
}

\author{
Barry S Komm \\ Sebastian Mirkin \\ Pfizer Inc, Collegeville, PA, USA
}

Correspondence: Barry S Komm

Pfizer Inc, 500 Arcola Rd,

Collegeville, PA 19426, USA

Tel + I 4848652776

Fax +I 484865432 I

Email barry.komm@pfizer.com

\begin{abstract}
Many women experience bothersome vasomotor and vaginal symptoms during the menopausal transition. Decreasing levels of estrogens during menopause are also associated with reduced bone density and an increased risk of osteoporosis. Combined estrogen/progestin therapy (hormone therapy) effectively treats menopausal symptoms and prevents bone loss, but has been associated with some safety and tolerability concerns. A novel menopausal therapy is the tissue selective estrogen complex, which pairs a selective estrogen receptor modulator with one or more estrogens. In preclinical studies, the tissue selective estrogen complex partnering bazedoxifene (BZA) with conjugated estrogens (CE) antagonized stimulation of breast and endometrial tissue, reduced vasomotor instability, and preserved bone mass in rat and mouse models. The specific attributes seen with BZA/CE were different from those observed with other selective estrogen receptor modulator/estrogen pairings. BZA/CE has undergone clinical evaluation in the Phase III Selective estrogens, Menopause, And Response to Therapy (SMART) trials in postmenopausal women with an intact uterus. Of the various doses of BZA/CE evaluated, BZA $20 \mathrm{mg} / \mathrm{CE} 0.45 \mathrm{mg}$ and $0.625 \mathrm{mg}$ were associated with a low incidence of endometrial hyperplasia $(<1 \%)$ similar to placebo, and showed significant improvements in hot flushes and vulvar/vaginal symptoms and increases in bone mineral density. BZA $20 \mathrm{mg} / \mathrm{CE} 0.45 \mathrm{mg}$ and $0.625 \mathrm{mg}$ were associated with a low incidence of breast-related adverse events and demonstrated no difference from placebo in age-related changes in mammographic breast density. Both BZA/ $\mathrm{CE}$ doses showed a favorable tolerability profile, with no increases in uterine bleeding or breast tenderness, and had positive effects on metabolic parameters and quality of life. BZA/CE may be a promising alternative to hormone therapy for the treatment of menopausal symptoms and prevention of osteoporosis in nonhysterectomized postmenopausal women.
\end{abstract}

Keywords: tissue selective estrogen complex, bazedoxifene, conjugated estrogens, menopause, osteoporosis, vasomotor symptoms

\section{Introduction}

Postmenopausal women may experience a variety of symptoms associated with a decline in the level of estrogens. ${ }^{1}$ Vasomotor symptoms (VMS), such as hot flushes, are reported by $60 \%-85 \%$ of women during menopause. ${ }^{2}$ Vulvar/vaginal atrophy (VVA; symptoms of which may include vaginal dryness, irritation, soreness, or dyspareunia, and increases in urinary frequency, urgency, or incontinence) is reported by $50 \%$ of postmenopausal women. ${ }^{3}$ The menopausal transition may also accelerate the rate of bone loss, leading to susceptibility to postmenopausal osteoporosis and associated fractures. ${ }^{4-6}$ In addition to the burden of the reduced quality of life (QoL) imposed by menopausal symptoms, the financial costs of menopausal treatments, lost productivity, and increased health care expenses present a significant economic burden. ${ }^{7}$ 
Many menopausal therapies are designed to treat individual symptoms. ${ }^{5}$ Topical estrogens or estradiol preparations such as creams, pessaries, tablets, and vaginal rings have been shown to be effective for the treatment of VVA. ${ }^{8}$ Tibolone has been shown to effectively treat VMS and VVA. ${ }^{9}$ Bisphosphonates, selective estrogen receptor modulators (SERMs), parathyroid hormone, estrogens, and calcitonin are approved pharmacologic agents for the prevention and/ or treatment of postmenopausal osteoporosis. ${ }^{10}$

The most common treatments for postmenopausal women who experience moderate-to-severe VMS along with other menopausal symptoms are estrogens and combined estrogen/ progestin or estradiol/progestin therapy (hormone therapy $[\mathrm{HT}]) .{ }^{11}$ HT options include conjugated estrogens (CE)/ medroxyprogesterone acetate (MPA), sequential estrogens/ trimegestone, drospirenone/estradiol, estradiol/norethindrone, and transdermal estradiol/norethindrone acetate. ${ }^{5}$ In addition to effectively treating VMS and VVA, estrogen monotherapy and HT have also shown efficacy in preventing postmenopausal osteoporosis and are considered comprehensive treatment options. ${ }^{11}$ Although the addition of progestins to estrogens provides protection against endometrial stimulation for postmenopausal women with a uterus, ${ }^{12,13}$ HT has been associated with some safety and tolerability concerns, including cardiovascular risk, breast stimulation, and irregular vaginal bleeding. ${ }^{11,14,15}$

A novel therapy currently under investigation for the treatment of menopausal symptoms and the prevention of osteoporosis is the tissue selective estrogen complex (TSEC), which pairs a SERM with one or more estrogens. ${ }^{16}$ SERMs have estrogen receptor (ER) agonist or antagonist activities depending on the target tissue. ${ }^{17,18}$ The goal of TSEC is to combine the established efficacy of estrogens on VMS, VVA, and bone with the protective effects of a SERM on the uterus and breast. ${ }^{16}$ The first TSEC in clinical development partners bazedoxifene (BZA) with CE. BZA is a SERM that has demonstrated efficacy in the treatment and prevention of osteoporosis with a favorable endometrial/breast safety profile in postmenopausal women. This review provides an overview of the key preclinical findings for BZA/CE and describes the results from the Phase III clinical trials of $\mathrm{BZA} / \mathrm{CE}$ in postmenopausal women with an intact uterus. The emerging role of TSEC in the current treatment paradigm for postmenopausal women is also discussed.

\section{Preclinical studies with BZA/CE In vitro studies}

BZA/CE was developed with the goal of achieving an optimal balance of ER agonist and antagonist activities.
Berrodin evaluated BZA/CE, raloxifene (RLX)/CE, and lasofoxifene (LAS)/CE in a multiplex biochemical assay. ${ }^{19}$ In this assay, BZA interacted with some cofactor peptides and not others, while LAS and RLX inhibited all of the peptides to which they were exposed. These results suggest that when combined with CE, BZA is more likely to exhibit tissue-selective effects than LAS or RLX. ${ }^{19}$ In a cell-based system of Michigan Cancer Foundation-7 (MCF-7) breast cancer cells, the global gene expression pattern associated with BZA/CE differed from that with RLX/CE or LAS/CE. The expression profile of BZA/CE was more similar to that with $\mathrm{CE}$ alone; in contrast, RLX/CE and LAS/CE had profiles that were similar to the SERM alone. ${ }^{19}$ In another study, the proliferation of MCF-7 cells was not induced by $\mathrm{BZA} / \mathrm{CE}$, although some proliferation was observed with $\mathrm{RLX} / \mathrm{CE}$ and $\mathrm{LAS} / \mathrm{CE} .^{20}$ These findings support a distinct activity profile for BZA/CE among other TSEC pairings in displaying agonist activity in some tissues and antagonist activity in others. ${ }^{19}$

\section{In vivo studies}

The effects of BZA, RLX, and LAS (all $3 \mathrm{mg} / \mathrm{kg}$ ) combined with estradiol $(1 \mu \mathrm{g} / \mathrm{kg})$ on breast and uterine tissues have been evaluated in ovariectomized (OVX) mice. ${ }^{21}$ In this model, BZA, RLX, and LAS prevented estradiol-induced increases in uterine wet weight $(P<0.05$ vs estradiol alone). BZA was a more effective antagonist of estradiolinduced increases in uterine wet weight than RLX or LAS ( $P<0.05$ vs estradiol/RLX or estradiol/LAS). In addition, treatment with BZA and RLX, but not LAS, reduced the estradiol-induced mammary gland end bud proliferation and all three SERMs significantly reduced the estradiol-induced expression of GPR105 and INDO mRNA markers of uterine and breast stimulation, respectively $(P<0.05$ vs estradiol alone for both markers). ${ }^{21}$

In a study of mature OVX rats treated with $\mathrm{BZA} / \mathrm{CE}$ daily for 6 weeks, ${ }^{16}$ the combination of BZA $3.0 \mathrm{mg} / \mathrm{kg}$ with CE $0.5,1.0$, or $2.5 \mathrm{mg} / \mathrm{kg}$ prevented CE-induced increases in uterine wet weight. Treatment with BZA 0.1, 0.3, 1.0, or $3.0 \mathrm{mg} / \mathrm{kg} / \mathrm{CE} 2.5 \mathrm{mg} / \mathrm{kg}$ and BZA $3.0 \mathrm{mg} / \mathrm{kg} / \mathrm{CE} 0.5$, $1.0,2.5$, or $5.0 \mathrm{mg} / \mathrm{kg}$ resulted in higher proximal tibia total bone mineral density (BMD) than with vehicle control $(P<0.01)$. CE $10.0 \mathrm{mg} / \mathrm{kg}$ significantly reduced tail skin temperature versus vehicle control in the morphine-addicted rat model of vasomotor instability. Addition of BZA 0.3, 3.0, or $10.0 \mathrm{mg} / \mathrm{kg}$ to $\mathrm{CE} 10.0 \mathrm{mg} / \mathrm{kg}$ maintained this response ( $P<0.05$ vs vehicle control). BZA $3.0 \mathrm{mg} / \mathrm{kg} / \mathrm{CE} 0.5$, $1.0,2.5$, or $5.0 \mathrm{mg} / \mathrm{kg}$ was also associated with significant 
decreases in serum total cholesterol compared with vehicle control $(P<0.01){ }^{16}$

The endometrial and breast effects of BZA/CE were further evaluated in OVX sexually immature mice. ${ }^{22}$ The minimal doses of BZA, RLX, and LAS that prevented $\mathrm{CE}$-induced increases in uterine wet weight were determined to be BZA $2 \mathrm{mg} / \mathrm{kg}$, RLX $10 \mathrm{mg} / \mathrm{kg}$, and LAS $2 \mathrm{mg} / \mathrm{kg}$. At these doses, the combinations of BZA and RLX with $\mathrm{CE}$ $3 \mathrm{mg} / \mathrm{kg}$ were more effective than LAS $2 \mathrm{mg} / \mathrm{kg} / \mathrm{CE} 3 \mathrm{mg} / \mathrm{kg}$ at preventing $\mathrm{CE}$-induced increases in uterine wet weight $(P<0.05)$. BZA was a better antagonist of CE-induced breast stimulation than RLX or LAS $(P<0.05)$, as measured by mammary gland amphiregulin mRNA expression. In an analysis of mammary gland whole mounts using these same SERM/CE doses, BZA/CE reduced the number of ductal branch points, a measure of ductal tree complexity, to a level similar to that with vehicle control and significantly lower than RLX/CE or LAS/CE $(P<0.05){ }^{22}$

The skeletal effects of BZA/CE were evaluated in OVX rats treated daily for 1 year with BZA $0.3 \mathrm{mg} / \mathrm{kg}, \mathrm{CE}$ $2.5 \mathrm{mg} / \mathrm{kg}$, or BZA $0.1,0.3$, or $1.0 \mathrm{mg} / \mathrm{kg} / \mathrm{CE} 2.5 \mathrm{mg} / \mathrm{kg}$. ${ }^{23}$ $\mathrm{BMD}$ of the lumbar spine and right proximal femur was significantly increased at 1 year compared with OVX control for all doses of BZA/CE $(P<0.05)$. Similarly, trabecular BMD of the proximal tibia metaphysis was significantly increased at 1 year with all doses of BZA/CE compared with OVX control $(P<0.05)$. Histomorphometry evaluation showed that all doses of $\mathrm{BZA} / \mathrm{CE}$ prevented the OVX-induced changes in static and dynamic parameters of the cortical compartment of the tibia and cancellous compartment of the L1 and L2 vertebrae. BZA 0.1 , 0.3 , and $1.0 \mathrm{mg} / \mathrm{kg} / \mathrm{CE} 2.5 \mathrm{mg} / \mathrm{kg}$ reduced uterine wet weights in a dose-dependent manner. BZA 0.1, 0.3, and $1.0 \mathrm{mg} / \mathrm{kg} / \mathrm{CE} 2.5 \mathrm{mg} / \mathrm{kg}$ were associated with significant decreases in serum total cholesterol compared with OVX control $(P<0.05)$.

Overall, preclinical studies have shown that BZA/CE effectively prevents stimulation of uterine and breast tissue in a variety of in vitro and in vivo models. BZA/CE has also been shown to preserve bone mass, reduce vasomotor effects, and reduce serum total cholesterol in OVX rats. These findings in preclinical models suggest that BZA/CE has the potential to effectively treat menopausal symptoms, prevent bone loss, and have favorable effects on the lipid profile while maintaining breast and endometrial safety in nonhysterectomized postmenopausal women. BZA/CE has been subsequently evaluated in a series of Phase III clinical trials.

\section{Clinical studies with BZA/CE}

The efficacy and safety of BZA/CE have been evaluated in multicenter, randomized, double-blind, placebo- and active-controlled, Phase III studies referred to as the Selective estrogens, Menopause, And Response to Therapy (SMART) trials (Table 1). These studies were conducted in postmenopausal women with an intact uterus, and assessed the efficacy, safety, and tolerability of BZA/CE in treating menopausal symptoms and preventing osteoporosis. Published reports of the Phase III studies of BZA/CE are described in this review.

The 2-year SMART-1 trial $(\mathrm{n}=3544)$ was conducted to evaluate the incidence of endometrial hyperplasia at 1 year in generally healthy women aged 40 to 75 years. ${ }^{24-27}$ Other endpoints included the effects of BZA/CE on BMD, bone turnover markers, VMS, VVA, safety, metabolic parameters, uterine bleeding, and QoL. The treatments evaluated in this trial were BZA 10, 20, and $40 \mathrm{mg} / \mathrm{CE} 0.45$ and $0.625 \mathrm{mg}$, RLX $60 \mathrm{mg}$, and placebo.

The SMART-2 trial $(n=332)^{28}$ evaluated the change from baseline in frequency and severity of hot flushes at 12 weeks in women aged 40 to 65 years who reported at least seven moderate-to-severe hot flushes per day (or $\geq 50$ per week) at baseline. The SMART-3 trial $(n=664)^{29}$ evaluated changes in four measures of VVA (the proportion of vaginal superficial cells, the proportion of parabasal cells, vaginal $\mathrm{pH}$, and severity of the most bothersome VVA symptom) in women aged 40 to 65 years who had at least one moderate-to-severe symptom of VVA at baseline. Secondary endpoints included effects on sleep (SMART-2 only), QoL, and safety. The treatments evaluated in these trials were BZA $20 \mathrm{mg} / \mathrm{CE} 0.45$ and $0.625 \mathrm{mg}$, BZA $20 \mathrm{mg}$ (SMART-3 only), and placebo.

\section{Efficacy on menopausal symptoms Vasomotor effects}

The efficacy of BZA/CE on VMS was evaluated by measuring the frequency and severity of hot flushes in response to treatment. In the SMART-1 trial, vasomotor effects were assessed in a subset of women from the overall study population who had at least seven moderate-to-severe hot flushes per day (or $\geq 50$ per week) at baseline $(n=216) .{ }^{24}$ At Week 12, treatment with all doses of BZA/CE significantly reduced the mean daily number of moderate and severe hot flushes from baseline (range, $-51.7 \%$ to $-85.7 \%$ ) compared with placebo $(-17.1 \% ; P<0.05)$. The mean change in hot flush severity from baseline to Week 12 was reduced for all doses of BZA/CE compared with placebo. These reductions were significant $(P<0.001)$ for BZA 10 and $20 \mathrm{mg} / \mathrm{CE} 0.45$ 
Table I Study designs for Phase III clinical trials of BZA/CE

\begin{tabular}{|c|c|c|c|}
\hline & SMART- I 24-27 & SMART-2 28 & SMART-329 \\
\hline Duration & 2 years & 12 weeks & 12 weeks \\
\hline Design & \multicolumn{3}{|c|}{ Randomized, double-blind, placebo-controlled, Phase III study } \\
\hline \multirow[t]{4}{*}{ Treatments } & BZA 10,20 , or $40 \mathrm{mg} / \mathrm{CE} 0.45$ & BZA $20 \mathrm{mg} / \mathrm{CE} 0.45$ & BZA $20 \mathrm{mg} / \mathrm{CE} 0.45$ \\
\hline & or $0.625 \mathrm{mg}$ & or $0.625 \mathrm{mg}$ & or $0.625 \mathrm{mg}$ \\
\hline & $\mathrm{RLX} 60 \mathrm{mg}$ & Placebo & BZA $20 \mathrm{mg}$ \\
\hline & Placebo & & Placebo \\
\hline \multirow[t]{5}{*}{ Enrolled } & \multicolumn{3}{|c|}{ Healthy, postmenopausal women with an intact uterus } \\
\hline & Aged $40-75$ years & Aged $40-65$ years & Aged $40-65$ years \\
\hline & & $\geq 7$ moderate-to-severe & $\geq \mathrm{I}$ moderate-to-severe \\
\hline & & hot flushes per day & symptom of VVA \\
\hline & & (or $\geq 50$ per week) & \\
\hline \multirow[t]{5}{*}{ Primary endpoints } & Incidence of & Frequency/severity & Four coprimary measures \\
\hline & endometrial hyperplasia & of hot flushes & of VVA (proportion of vaginal \\
\hline & & & superficial cells, proportion \\
\hline & & & of parabasal cells, vaginal pH, \\
\hline & & & most bothersome symptom) \\
\hline \multirow[t]{4}{*}{ Secondary endpoints } & BMD, BTM, & Sleep, QoL & Sexual function, satisfaction \\
\hline & frequency/severity of & & with treatment, QoL \\
\hline & hot flushes, measures & & \\
\hline & of VVA, sleep, QoL & & \\
\hline
\end{tabular}

Abbreviations: BZA, bazedoxifene; CE, conjugated estrogens; SMART, Selective estrogens, Menopause, And Response to Therapy; RLX, raloxifene; VVA, vulvar vaginal atrophy; BMD, bone mineral density; BTM, bone turnover markers; QoL, quality of life.

and $0.625 \mathrm{mg}$. The significant treatment effects on hot flush frequency and severity with BZA 10 and $20 \mathrm{mg} / \mathrm{CE} 0.45$ and $0.625 \mathrm{mg}$ were maintained through 2 years. ${ }^{24}$

The SMART-2 trial evaluated the efficacy of VMS on a larger population of symptomatic women $(n=332)$. At Week 12, ${ }^{28}$ treatment with BZA $20 \mathrm{mg} / \mathrm{CE} 0.45$ and $0.625 \mathrm{mg}$ significantly reduced the number of hot flushes from baseline by $74 \%$ and $80 \%$, respectively, compared to $51 \%$ with placebo $(P<0.001$; Figure 1$)$. The mean daily hot flush severity was also significantly reduced for BZA $20 \mathrm{mg} / \mathrm{CE} 0.45$ and $0.625 \mathrm{mg}$ compared with placebo at Week $12(P<0.001)$. With BZA $20 \mathrm{mg} / \mathrm{CE} 0.45$ and $0.625 \mathrm{mg}$, $61 \%$ and $73 \%$ of women, respectively, had a $75 \%$ or greater decrease in the mean number of hot flushes than those treated with placebo $(27 \% ; P<0.001)$ at Week $12 .^{28}$

\section{Effects on VVA}

The efficacy of BZA/CE in treating VVA symptoms was evaluated by changes in the degree of maturation of the vaginal epithelium, measured by the proportion of superficial, intermediate, and parabasal cells on a vaginal smear. ${ }^{24}$ In the SMART-1 trial, VVA was assessed in a subset of women from the overall study population who had no more than $5 \%$ superficial cells at baseline $(\mathrm{n}=1867) .{ }^{24}$ At Month 24, BZA 10 and $20 \mathrm{mg} / \mathrm{CE} 0.45$ and $0.625 \mathrm{mg}$ were associated with a significant increase in superficial cells compared with placebo $(P<0.001$ for BZA $10 \mathrm{mg} / \mathrm{CE} 0.45$ and $0.625 \mathrm{mg}$;
$P<0.01$ for BZA $20 \mathrm{mg} / \mathrm{CE} 0.625 \mathrm{mg}$ ). There was a significant increase in intermediate cells and a significant decrease in parabasal cells with BZA 10 and $20 \mathrm{mg} / \mathrm{CE}$ 0.45 and $0.625 \mathrm{mg}$ compared with placebo $(P<0.001$ for all). BZA $10 \mathrm{mg} / \mathrm{CE} 0.625 \mathrm{mg}$ and BZA $20 \mathrm{mg} / \mathrm{CE} 0.45$ and $0.625 \mathrm{mg}$ were also associated with a lower incidence of dyspareunia (defined as pain during sexual intercourse) than placebo $(P<0.05)$ during Weeks 9 to $12 .^{24}$

Similar to the subset within the SMART-1 trial, the SMART-3 trial enrolled women with at least one moderateto-severe VVA symptom. BZA $20 \mathrm{mg} / \mathrm{CE} 0.45$ and $0.625 \mathrm{mg}$ significantly increased superficial cells $(P \leq 0.001)$, decreased parabasal cells $(P \leq 0.001)$, and increased intermediate cells $(P<0.01$ for BZA $20 \mathrm{mg} / \mathrm{CE} 0.45 \mathrm{mg} ; P \leq 0.001$ for BZA $20 \mathrm{mg} / \mathrm{CE} 0.625 \mathrm{mg}$ ) compared with placebo at 12 weeks. $^{29}$ Mean vaginal $\mathrm{pH}$ significantly decreased from baseline to Week 12 for both doses of BZA/CE $(P<0.001)$. With BZA $20 \mathrm{mg} / \mathrm{CE} 0.625 \mathrm{mg}$, but not BZA $20 \mathrm{mg} / \mathrm{CE} 0.45 \mathrm{mg}$, severity scores for the vaginal symptom originally identified by each woman as the most bothersome were significantly improved at Week 12 compared with placebo $(P=0.048)$. At Week 12 , $81 \%$ of women treated with BZA $20 \mathrm{mg} / \mathrm{CE} 0.625 \mathrm{mg}$ and $78 \%$ of women treated with BZA $20 \mathrm{mg} / \mathrm{CE} 0.45 \mathrm{mg}$ had responded to treatment (defined as vaginal superficial cells $>5 \%$, vaginal $\mathrm{pH}<5$, and/or improvement from baseline in most bothersome vaginal symptom) compared with $66 \%$ of women given placebo $(P=0.005$ and $P=0.027$, respectively $){ }^{29}$ 


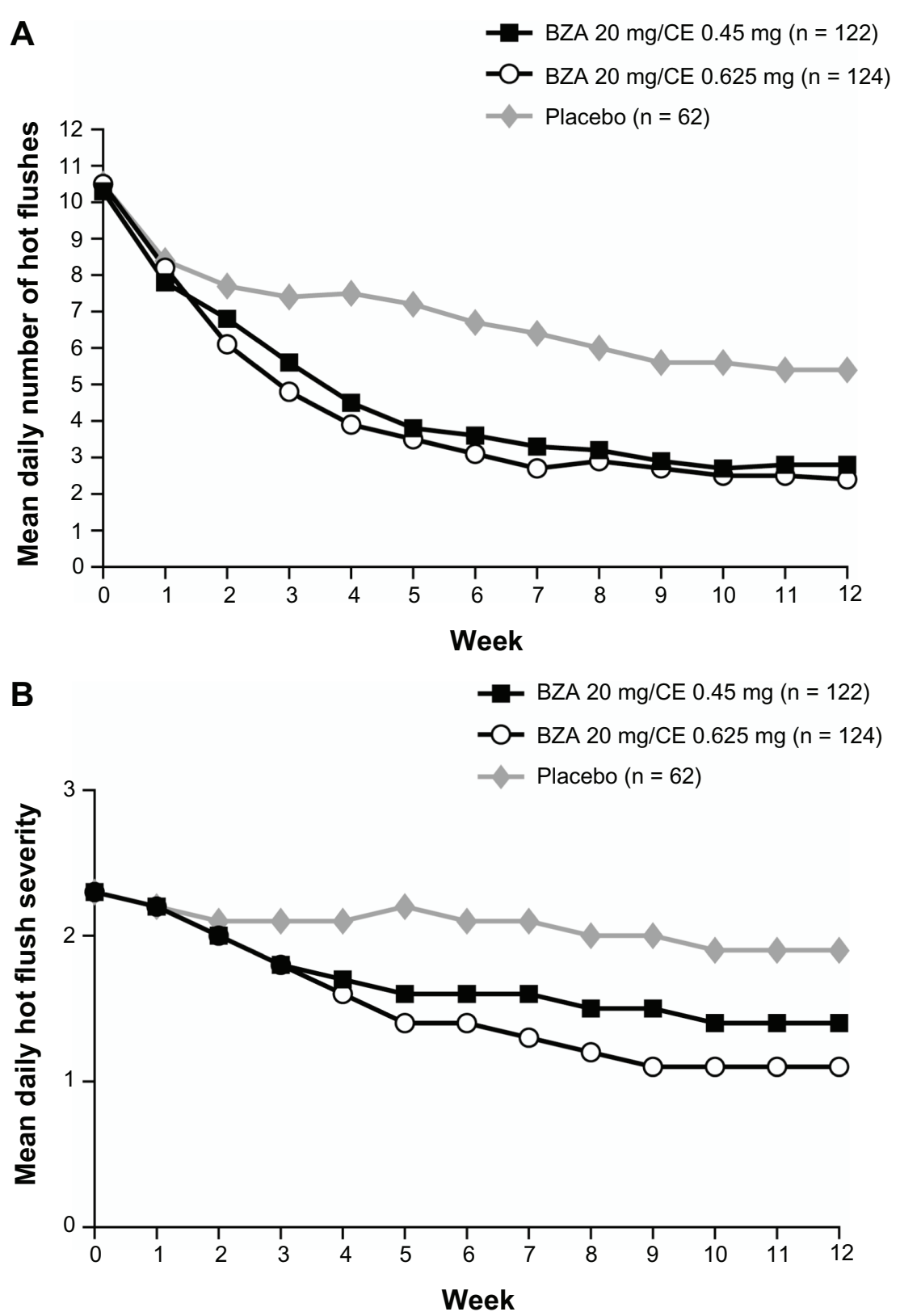

Figure I The mean daily number (A) and severity (B) of moderate-to-severe hot flushes over 12 weeks in the SMART-2 trial.

Copyright (C) 2009, Wolters Kluwer Health. Reprinted with permission from Pinkerton JV, Utian WH, Constantine GD, Olivier S, Pickar JH. Relief of vasomotor symptoms with the tissue-selective estrogen complex containing bazedoxifene/conjugated estrogens: a randomized, controlled trial. Menopause. 2009; I6(6): I I I6-I I24.

Abbreviations: SMART, Selective estrogens, Menopause, And Response to Therapy; BZA, bazedoxifene; CE, conjugated estrogens.

\section{Bone effects}

The efficacy of BZA/CE in preventing bone loss was evaluated by changes in BMD as measured by dual-energy $\mathrm{X}$-ray absorptiometry; changes in bone turnover markers (surrogate markers of bone formation and bone resorption) were also assessed. Although there has been some variability associated with bone turnover marker measurements, these markers are widely used to evaluate bone metabolism and treatment response to bone-active therapies..$^{30}$ Effects on BMD were evaluated in two substudies within the SMART-1 trial, in women who were between 1 and 5 years since menopause (YSM) and in those who were greater than 5 YSM. All doses of BZA/CE significantly increased lumbar spine and total hip BMD compared with placebo at 2 years in the SMART- 1 trial $(P<0.001$ for lumbar spine for all women, $P<0.01$ for total hip in women $1-5$ YSM, and $P<0.001$ for total hip in women $>5$ YSM; Figure 2) ${ }^{26}$

Changes from baseline in C-telopeptide and osteocalcin were measured in women who were between 1 and 5 YSM. At 2 years, the median percent change in levels of 

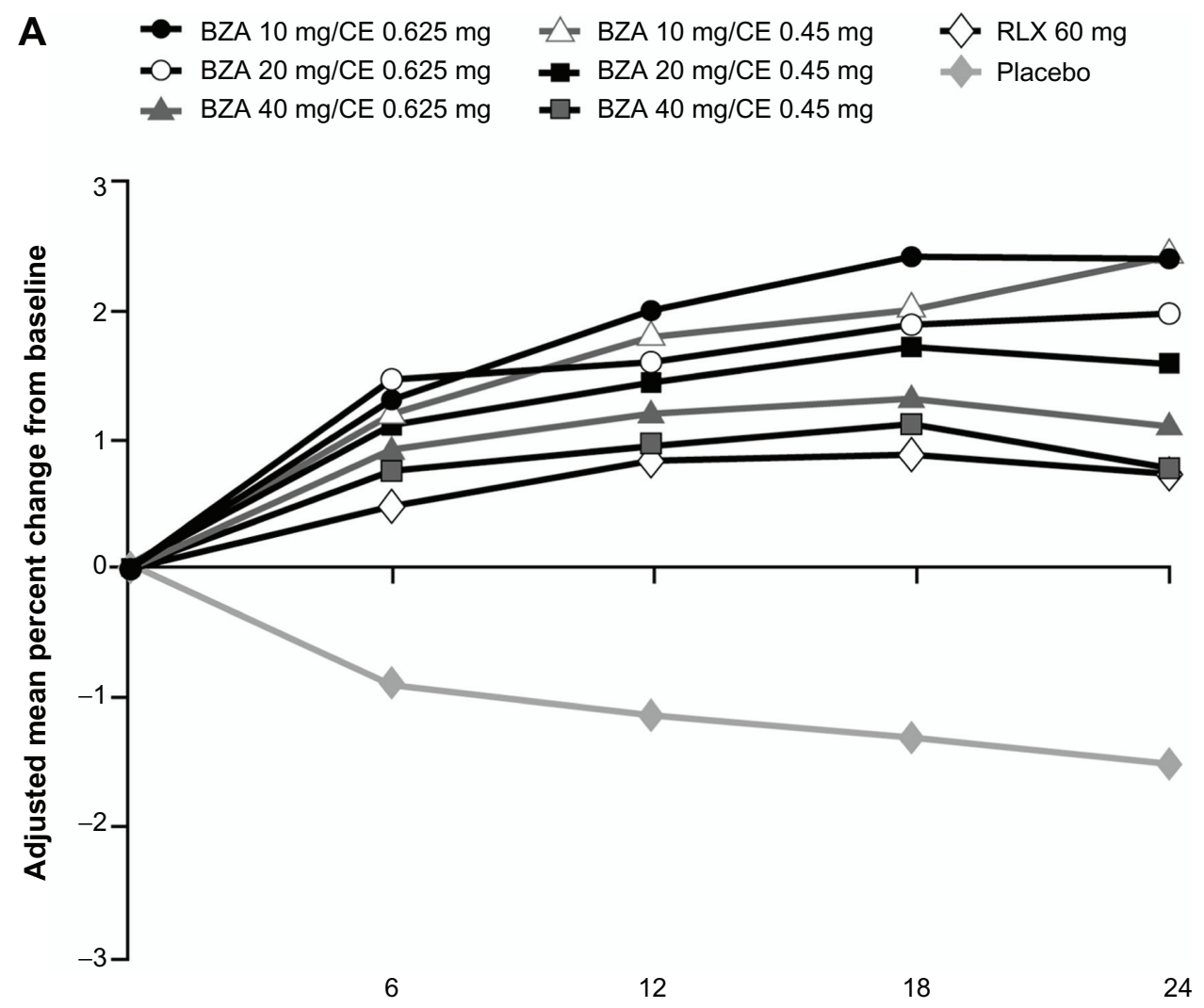

\section{Months}

B
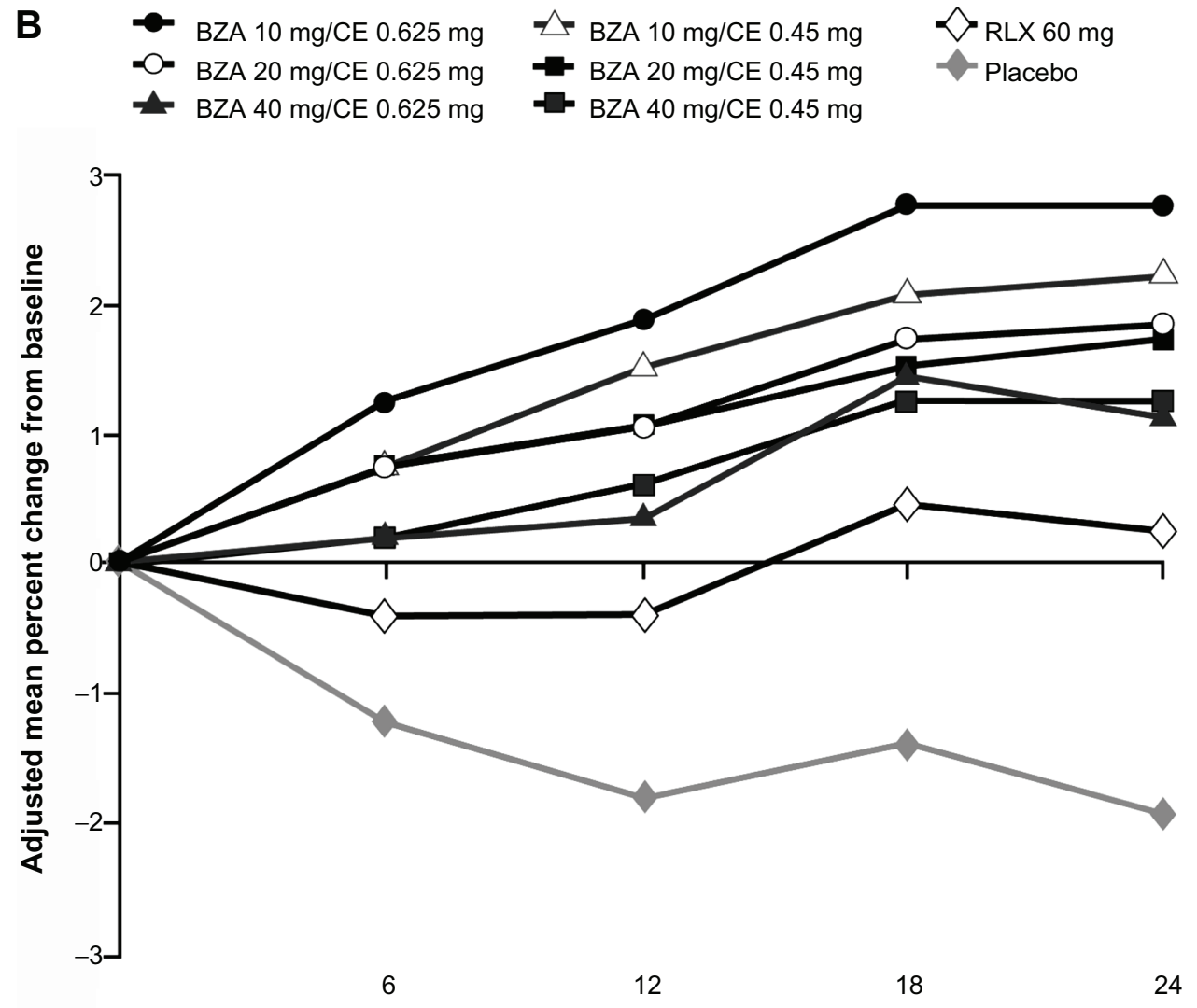

Months

Figure 2 (Continued) 

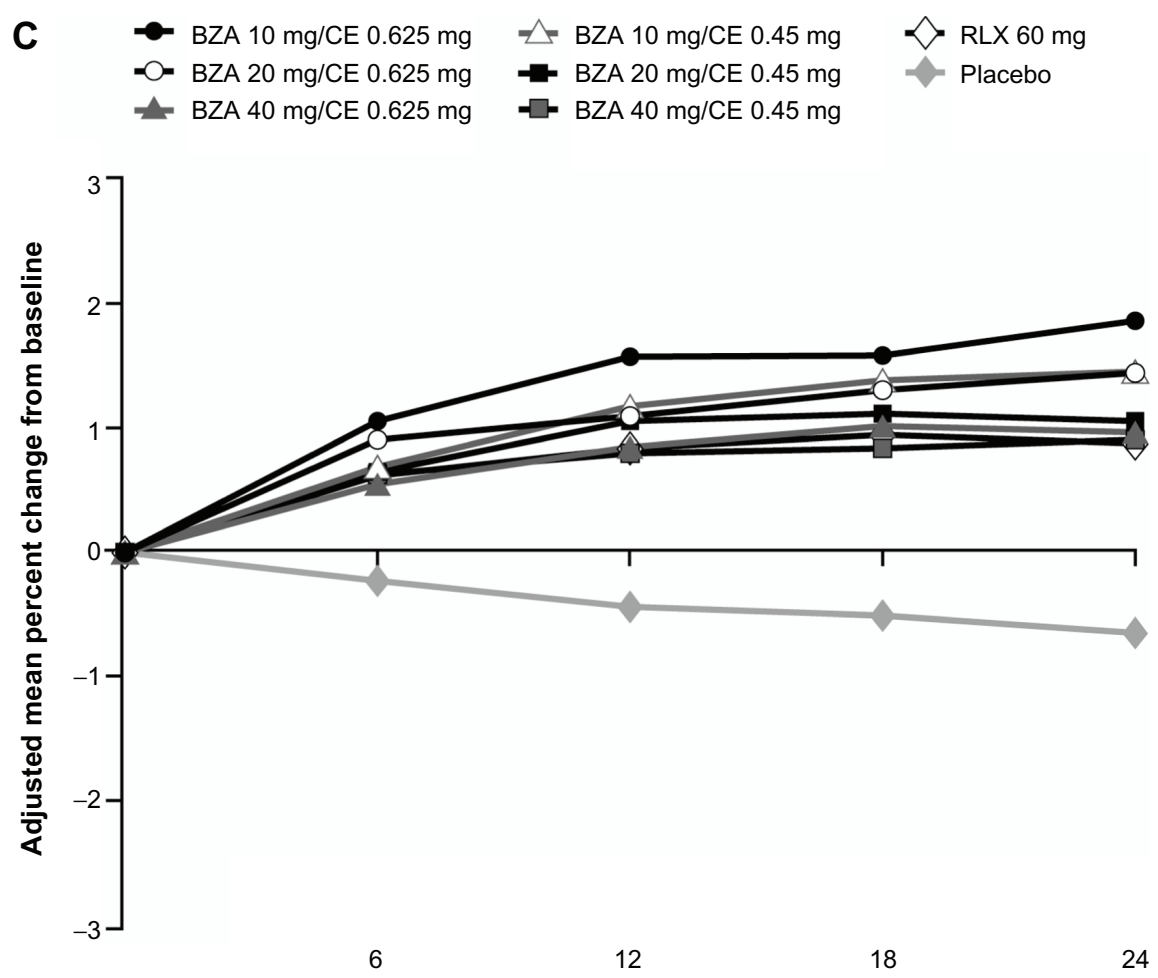

Months
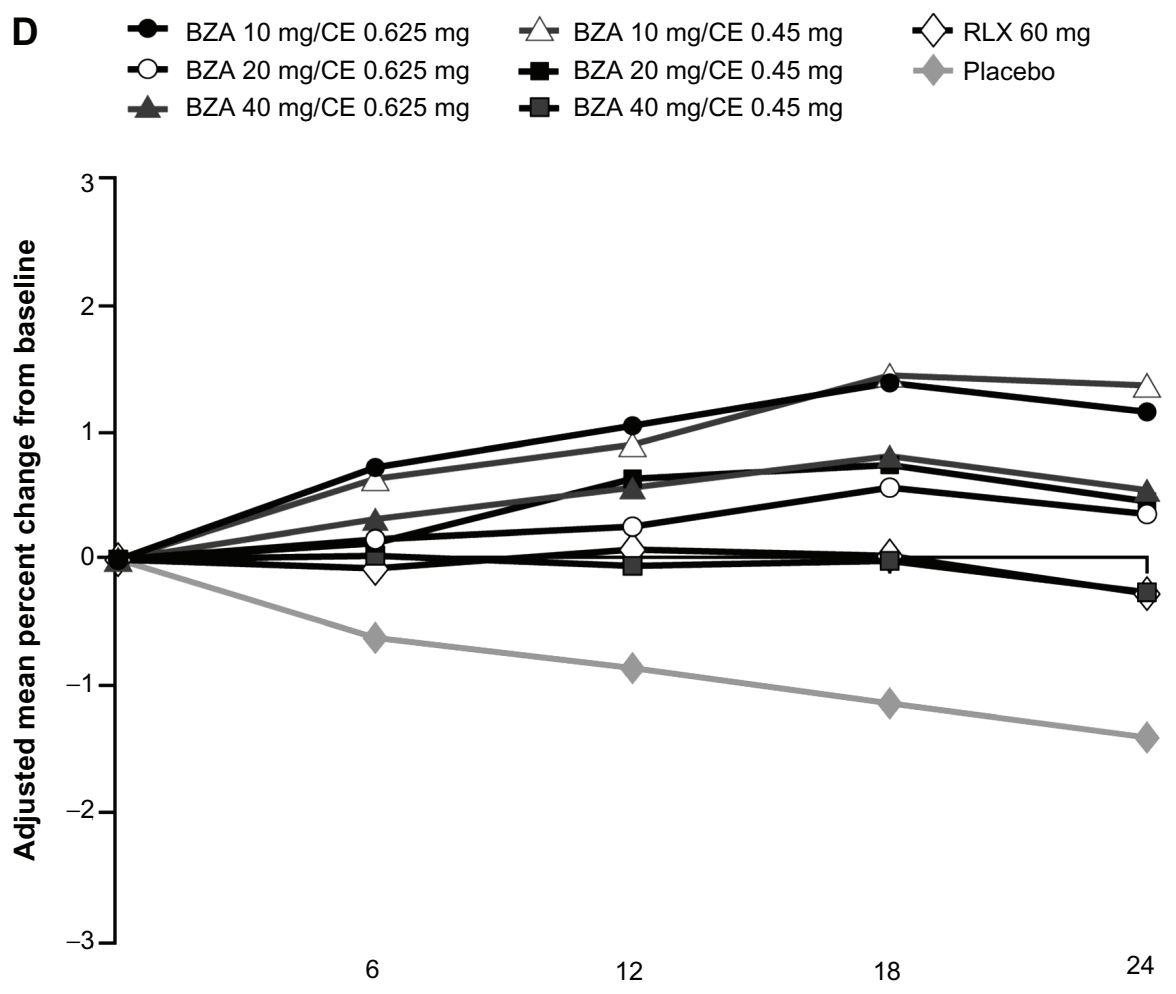

Months

Figure 2 Adjusted mean percent change in BMD from baseline over 2 years in the SMART-I trial.

Copyright @ 2009, Elsevier. Reprinted with permission from Lindsay R, Gallagher JC, Kagan R, Pickar JH, Constantine G. Efficacy of tissue-selective estrogen complex of bazedoxifene/conjugated estrogens for osteoporosis prevention in at-risk postmenopausal women. Fertil Steril. 2009;92:1045-1052.

Notes: Lumbar spine BMD was evaluated for women $>5$ YSM (A), or between I and 5 YSM (B); total hip BMD was evaluated for women $>5$ YSM (C), or between I and 5 YSM (D).

Abbreviations: BMD, bone mineral density; SMART, Selective estrogens, Menopause And Response to Therapy; YSM, years since menopause; BZA, bazedoxifene; CE, conjugated estrogens; RLX, raloxifene. 
C-telopeptide (range, $-42.72 \%$ to $-53.40 \%$ ) and osteocalcin (range, $-19.78 \%$ to $-28.05 \%$ ) with all doses of BZA/CE were significantly reduced compared with placebo $(-13.81 \%$ and $3.08 \%$, respectively; $P<0.001$ for all). ${ }^{26}$

\section{Safety \\ Endometrial safety}

In the SMART-1 trial, endometrial safety was assessed by the incidence of endometrial hyperplasia, which has been used as a surrogate marker for endometrial cancer. ${ }^{27}$ In the SMART-1 trial, endometrial biopsy results showed one case of endometrial hyperplasia $(0.32 \%)$ with BZA $20 \mathrm{mg} / \mathrm{CE} 0.625 \mathrm{mg}$ and no cases with BZA $20 \mathrm{mg} / \mathrm{CE}$ $0.45 \mathrm{mg}$ or BZA $40 \mathrm{mg} / \mathrm{CE} 0.45$ or $0.625 \mathrm{mg}$ at 1 year. These hyperplasia rates were not significantly different from placebo or RLX $60 \mathrm{mg}$. With BZA $10 \mathrm{mg} / \mathrm{CE} 0.45$ and $0.625 \mathrm{mg}$, there were three cases $(0.94 \%)$ and 13 cases $(3.81 \%)$ of endometrial hyperplasia, respectively. The $3.81 \%$ rate of endometrial hyperplasia with BZA $10 \mathrm{mg} / \mathrm{CE} 0.625 \mathrm{mg}$ was determined to be unacceptable per study criteria. ${ }^{27}$ As a result, further investigations of $\mathrm{BZA} / \mathrm{CE}$ have focused on doses of BZA $20 \mathrm{mg} / \mathrm{CE} 0.45$ and $0.625 \mathrm{mg}$.

\section{Breast safety}

High mammographic breast density has been shown to be a moderate independent risk factor for breast cancer. ${ }^{31,32}$ The effects of BZA/CE on age-related changes in mammographic breast density were evaluated in an ancillary study of the SMART-1 trial. Findings showed that the change in baseline breast density was similar for BZA $20 \mathrm{mg} / \mathrm{CE}$ $0.45 \mathrm{mg}(-0.39 \%)$, BZA $20 \mathrm{mg} / \mathrm{CE} 0.625 \mathrm{mg}(-0.05 \%)$, RLX $60 \mathrm{mg}(-0.23 \%)$, and placebo $(-0.42 \%)$ over 2 years of treatment. ${ }^{33}$ The incidence of breast cancer in the SMART-1 trial was low and similar for BZA $20 \mathrm{mg} / \mathrm{CE} 0.45 \mathrm{mg}(\mathrm{n}=1)$, BZA $20 \mathrm{mg} / \mathrm{CE} 0.625 \mathrm{mg}(\mathrm{n}=0)$, and placebo $(\mathrm{n}=1)$ over 2 years. ${ }^{34}$ There was no significant difference in the incidence of abnormal mammograms for BZA $20 \mathrm{mg} / \mathrm{CE} 0.45 \mathrm{mg}$ (4.4\%), BZA $20 \mathrm{mg} / \mathrm{CE} 0.625 \mathrm{mg}$ (4.2\%), and placebo $(2.6 \%) .{ }^{35,34}$ In a pooled analysis of data from the SMART-1, SMART-2, and SMART-3 trials, the incidence of breastrelated adverse events (AEs) was low $(<0.3 \%)$ and similar for BZA $20 \mathrm{mg} / \mathrm{CE} 0.45 \mathrm{mg}$ and placebo (BZA $20 \mathrm{mg} / \mathrm{CE}$ $0.625 \mathrm{mg}$ was not included in this analysis). ${ }^{35}$ There were no reports of fibrocystic breast disease or breast mass with BZA $20 \mathrm{mg} / \mathrm{CE} 0.45 \mathrm{mg}$ or placebo in these three trials. ${ }^{35}$ Together, these results suggest that BZA/CE has a neutral effect on the breast.

\section{General safety and tolerability}

Among all the SMART trials, the overall incidence of treatment-emergent AEs was similar among groups. ${ }^{24,28,29}$ There were no significant differences between the BZA/CE and placebo groups in the percentage of women reporting breast pain in the SMART-1, SMART-2, and SMART-3 trials. ${ }^{24,28,29}$ In the SMART-1 trial, BZA $20 \mathrm{mg} / \mathrm{CE} 0.45$ and $0.625 \mathrm{mg}$ were associated with low rates of bleeding/spotting and high rates of amenorrhea over consecutive 4-week cycles ( $>83 \%$ during Cycles 1-13 and $>93 \%$ during Cycles 10-13 during Year 1), with no significant differences compared with placebo. ${ }^{25}$

\section{Venous thromboembolic events}

In the SMART-1 trial, the incidence of venous thromboembolic events (VTEs) was 0.75 per 1000 woman-years for the combined BZA/CE treatment groups compared with 1.56 per 1000 woman-years for the placebo group (relative risk, 0.48; 95\% confidence interval, 0.05-4.66). These VTEs included one report of deep vein thrombosis in each of the BZA $10 \mathrm{mg} / \mathrm{CE} 0.625 \mathrm{mg}$ and BZA $40 \mathrm{mg} / \mathrm{CE} 0.625 \mathrm{mg}$ groups and one case of deep vein thrombosis in the placebo group, as well as one case of pulmonary embolism with BZA $40 \mathrm{mg} / \mathrm{CE} 0.625 \mathrm{mg} .{ }^{24}$ No VTEs were reported in the SMART-2 or SMART-3 trials, but these studies were of 12-week duration. ${ }^{28,29}$

\section{Lipid and coagulation parameters Lipids}

Women may experience adverse changes to the metabolic profile during the menopausal transition, including increases in total cholesterol, triglycerides, low-density lipoprotein (LDL) cholesterol, and lipoprotein (a) and decreases in high-density lipoprotein (HDL) cholesterol. ${ }^{36}$ The effects of BZA/CE on lipid parameters were evaluated in the SMART-1 trial. At Month 24, BZA $20 \mathrm{mg} / \mathrm{CE} 0.45$ and $0.625 \mathrm{mg}$ were associated with decreases from baseline in total cholesterol $(P<0.05$ vs placebo for BZA $20 \mathrm{mg}$ / CE $0.45 \mathrm{mg})$ and LDL cholesterol $(P<0.01$ vs placebo for both). HDL cholesterol increased from baseline $(P<0.01$ vs placebo) with BZA $20 \mathrm{mg} / \mathrm{CE} 0.45$ and $0.625 \mathrm{mg}$, as did triglyceride $(P<0.01)$, HDL-2 cholesterol $(P<0.001)$, and apolipoprotein A1 $(P<0.001)$ levels compared with placebo. BZA $20 \mathrm{mg} / \mathrm{CE} 0.45$ and 0.625 also showed significant decreases from baseline in apolipoprotein B $(P<0.05)$ and lipoprotein $(a)(P<0.01)$ versus placebo. ${ }^{24}$ 
At Week 12 of the SMART-2 trial, both doses of BZA/CE were associated with significant decreases from baseline compared with placebo in total and LDL cholesterol. HDL cholesterol decreased from baseline over 12 weeks with placebo, but was maintained at baseline levels with BZA/ CE. Triglyceride levels significantly increased from baseline with BZA $20 \mathrm{mg} / \mathrm{CE} 0.45$ and $0.625 \mathrm{mg}$ and with placebo. The increase in triglycerides was clinically important for more women in the placebo group than in either BZA/CE group $(P=0.04) .{ }^{28}$

Both doses of BZA/CE were associated with significant decreases in LDL cholesterol $(P<0.01)$ at Week 12 in the SMART-3 trial. BZA $20 \mathrm{mg} / \mathrm{CE} 0.625 \mathrm{mg}$ showed a small increase in triglyceride levels that was statistically significant compared with placebo $(P<0.05) .{ }^{29}$

\section{Coagulation parameters}

Changes in coagulation factors have been shown to occur during the menopausal transition, such as increases in levels of the coagulation proteins factor VII and fibrinogen. ${ }^{36}$ The effects of BZA/CE on coagulation parameters were evaluated in the SMART-1 trial. At Month 24, there were significant decreases from baseline in levels of fibrinogen $(P<0.001)$, protein S activity $(P<0.01)$, and antithrombin III activity $(P<0.05$ and $P<0.01)$ for BZA $20 \mathrm{mg} / \mathrm{CE} 0.45$ and $0.625 \mathrm{mg}$ compared with placebo. ${ }^{24}$ Neither dose of BZA/CE affected partial thromboplastin time, prothrombin time, or D-dimer levels. There were small decreases from baseline with BZA $20 \mathrm{mg} / \mathrm{CE} 0.45$ and $0.625 \mathrm{mg}$ in plasminogen activator inhibitor-1 activity $(P<0.05$ for both doses) and plasminogen activator inhibitor-1 antigen levels $(P<0.05$ for BZA $20 \mathrm{mg} / \mathrm{CE} 0.625 \mathrm{mg}$ ). Plasminogen activity was significantly increased from baseline with BZA $20 \mathrm{mg} / \mathrm{CE}$ 0.45 and $0.625 \mathrm{mg}(P<0.001){ }^{24}$

\section{Sleep, QoL, and satisfaction}

During menopause, many women experience bothersome symptoms such as VMS, mood disturbances, or sexual dysfunction, which may negatively impact QoL. ${ }^{7}$ Sleep disruptions, including increased time to fall asleep, nighttime awakenings, and daytime tiredness, are also common among postmenopausal women. ${ }^{37}$ The effects of BZA/CE on sleep parameters were evaluated in the SMART-1 trial using daily diaries and in the SMART-2 trial using the Medical Outcomes Study sleep scale. Impact on QoL measures was assessed in each SMART trial using the Menopausespecific Quality Of Life (MENQOL) questionnaire. In the
SMART-3 trial, effects on sexual function were assessed using the Arizona Sexual Experiences scale. Satisfaction with treatment was evaluated in the SMART-2 and SMART-3 trials as measured by the Menopause Symptoms Treatment Satisfaction Questionnaire.

\section{Sleep}

In the SMART-1 trial, women treated with BZA $20 \mathrm{mg} /$ CE 0.45 and $0.625 \mathrm{mg}$ had significant reductions in mean minutes to fall asleep ( -11.6 and -10.9 minutes, respectively), increases in mean minutes slept (22.6 and 19.7 minutes, respectively), and increases in quality of sleep score ( 0.29 and 0.27 , respectively) compared with placebo ( -5.6 minutes, 10.1 minutes, and 0.13 , respectively; $P<0.05)$ at 13 weeks. ${ }^{38}$ In a subset of women who had at least seven hot flushes per day at baseline $(\mathrm{n}=81)$, BZA $20 \mathrm{mg} / \mathrm{CE}$ 0.45 and $0.625 \mathrm{mg}$ improved mean minutes slept and quality of sleep score, but did not affect time to fall asleep (this analysis was not powered to show statistical significance). ${ }^{38}$ In the SMART-2 trial, BZA $20 \mathrm{mg} / \mathrm{CE} 0.45$ and $0.625 \mathrm{mg}$ significantly improved time to fall asleep, sleep disturbance, sleep adequacy, and overall sleep problems indexes I and II compared with placebo $(P<0.001$ for all $)$ at 12 weeks in the SMART-2 trial as assessed on the Medical Outcomes Study sleep scale. ${ }^{39}$

\section{QoL}

At Week 12 in the SMART-1 trial, BZA $20 \mathrm{mg} / \mathrm{CE} 0.45$ and $0.625 \mathrm{mg}$ significantly improved total $(-0.7$ and -0.8 , respectively) and vasomotor function $(-1.2$ and -1.5 , respectively) MENQOL scores compared with placebo $(-0.5$ for both domains; $P<0.001){ }^{40}$ Similar results were observed in the SMART-2 trial in which BZA $20 \mathrm{mg} / \mathrm{CE}$ 0.45 and $0.625 \mathrm{mg}$ significantly improved total $(-1.6$ and -1.9 , respectively) and vasomotor function ( -3.3 and -3.8 , respectively) MENQOL scores compared with placebo ( -1.0 and -1.6 , respectively; $P<0.001) .{ }^{39,40}$ In the SMART-3 trial, women treated with BZA $20 \mathrm{mg} / \mathrm{CE} 0.45$ and $0.625 \mathrm{mg}$ reported significant improvements in ease of lubrication on the Arizona Sexual Experiences scale $(-0.82$ and -0.85 , respectively) compared with placebo $(-0.50 ; P<0.05)$. BZA $20 \mathrm{mg} / \mathrm{CE} 0.45$ and $0.625 \mathrm{mg}$ were also associated with significant improvements from baseline in the total ( -1.09 and -1.18 , respectively), vasomotor $(-1.33$ and -1.67 , respectively), and sexual ( -1.95 and -1.91 , respectively) function compared with placebo $(-0.67,-0.51$, and -1.24 , respectively; $P<0.001$ for all). ${ }^{41}$ 


\section{Treatment satisfaction}

In the SMART-2 trial, Menopause Symptoms Treatment Satisfaction Questionnaire results showed that $73.5 \%$ of women treated with BZA $20 \mathrm{mg} / \mathrm{CE} 0.45 \mathrm{mg}$ and $78.2 \%$ of women treated with BZA $20 \mathrm{mg} / \mathrm{CE} 0.625 \mathrm{mg}$ were satisfied with treatment compared with $44.4 \%$ of women given placebo $(P<0.001)$. In particular, women treated with BZA $20 \mathrm{mg} / \mathrm{CE} 0.45$ and $0.625 \mathrm{mg}$ showed significantly higher satisfaction than those given placebo in the categories of ability to control hot flushes during the day $(P<0.001)$ and during the night $(P<0.001)$, effect on quality of sleep $(P<0.001)$, and effect on mood and emotions $(P<0.05) .{ }^{39}$ Similarly, in the SMART-3 trial, $62.6 \%$ of women treated with BZA $20 \mathrm{mg} / \mathrm{CE} 0.45 \mathrm{mg}$ and $69.4 \%$ of women treated with BZA $20 \mathrm{mg} / \mathrm{CE} 0.625 \mathrm{mg}$ were satisfied with treatment compared with $47.5 \%$ of women given placebo $(P<0.05$ and $P<0.001$, respectively). Significantly greater proportions of women treated with BZA $20 \mathrm{mg} / \mathrm{CE} 0.45$ and $0.625 \mathrm{mg}$ were satisfied with their ability to control hot flushes during the day $(P<0.001)$ and during the night $(P<0.001)$, effect on mood or emotions $(P<0.05)$, and effect on quality of sleep $(P<0.001)$ compared with placebo at 12 weeks. ${ }^{41}$

\section{Conclusion}

The TSEC is a novel menopausal therapy that has been developed to blend the uterine- and breast-protective effects of a SERM in women with a uterus with the established benefits of estrogens on VMS, VVA, and bone. TSECs, such as BZA/ $\mathrm{CE}$, may be an appropriate alternative to HT for women with concerns about the potential safety risks of HT (combined estrogen/progestin or estradiol/progestin therapy) such as cardiovascular risk and breast stimulation. ${ }^{11,14,15}$ Tolerability concerns include breast pain and irregular vaginal bleeding. ${ }^{11}$

Preclinical studies showed that BZA/CE has favorable vasomotor effects and prevents bone loss in OVX rats while minimizing stimulation of uterine and breast tissue in a variety of in vitro and in vivo models. Furthermore, the tissue-selective effects of BZA/CE were distinct from those of RLX/CE or LAS/CE. BZA was shown to be a stronger antagonist of CE-induced breast cancer cell proliferation and mammary gland end bud formation than RLX or LAS. BZA and RLX were more effective in inhibiting CE-induced increases in uterine wet weight than was LAS.

In Phase III clinical studies, BZA $20 \mathrm{mg} / \mathrm{CE} 0.45$ and $0.625 \mathrm{mg}$ were shown to significantly reduce the frequency/ severity of hot flushes and improve VVA measures in symptomatic postmenopausal women. These BZA/CE doses also significantly increased BMD at the lumbar spine and total hip while preventing endometrial stimulation, as shown by low rates of endometrial hyperplasia similar to those with placebo.

Results of the SMART trials showed that treatment with BZA $20 \mathrm{mg} / \mathrm{CE} 0.45$ and $0.625 \mathrm{mg}$ maintained breast safety, with low rates of breast-related AEs and no changes in breast density. In contrast, HT use has been reported to increase mammographic breast density, ${ }^{42-44}$ and long-term estrogen plus progestin therapy has been associated with an increased risk of breast cancer. ${ }^{11}$ Study findings also showed that BZA/ $\mathrm{CE}$ has a favorable tolerability profile, with incidences of bleeding/spotting and breast tenderness that were low and similar compared with placebo. These results contrast those reported for HT, which has been associated with increased rates of bleeding/spotting as well as breast pain/tenderness compared with placebo. ${ }^{45} \mathrm{BZA} / \mathrm{CE}$ also showed positive effects on coagulation factors and improvements in lipid parameters in the SMART trials, including decreases in total and LDL cholesterol and increases in HDL cholesterol. These effects on blood lipids with BZA/CE have been shown to be similar to those observed with $\mathrm{CE}$ alone and with CE/MPA. ${ }^{46}$

BZA/CE has demonstrated significant improvements in sleep parameters, including time to fall asleep and overall sleep scores. Studies of HT have also shown improvements in sleep, although the effects were relatively small. ${ }^{47-50} \mathrm{BZA} / \mathrm{CE}$ also showed significant improvements in total and vasomotor function in all three SMART trials; in comparison, the effects of HT on QoL parameters have been mixed. ${ }^{47,48,51-53}$

Overall, BZA/CE has been shown to be generally safe and well tolerated over 2 years of treatment in postmenopausal women and is associated with high rates of treatment satisfaction. Collectively, these data suggest that BZA/CE is a promising option for the comprehensive treatment of menopausal symptoms and prevention of postmenopausal osteoporosis. Further studies are needed to determine the long-term efficacy and safety of BZA/CE in postmenopausal women.

\section{Acknowledgments}

Medical writing support for this manuscript was provided by Katie Gersh, PhD, of MedErgy, and was funded by Pfizer Inc. The authors retained full editorial control over the content of the article.

\section{Disclosure}

BSK and SM are employees of Pfizer Inc. 


\section{References}

1. Burger HG. The endocrinology of the menopause. Maturitas. 1996;23(2): 129-136.

2. Gold EB, Colvin A, Avis N, et al. Longitudinal analysis of the association between vasomotor symptoms and race/ethnicity across the menopausal transition: study of women's health across the nation. $\mathrm{Am}$ J Public Health. 2006;96(7):1226-1235.

3. Mac Bride MB, Rhodes DJ, Shuster LT. Vulvovaginal atrophy. Mayo Clin Proc. 2010;85(1):87-94.

4. Riggs BL, Khosla S, Melton LJ III. A unitary model for involutional osteoporosis: estrogen deficiency causes both type I and type II osteoporosis in postmenopausal women and contributes to bone loss in aging men. J Bone Miner Res. 1998;13(5):763-773.

5. Lewis V. Undertreatment of menopausal symptoms and novel options for comprehensive management. Curr Med Res Opin. 2009;25(11): 2689-2698.

6. National Osteoporosis Foundation. Fast Facts on Osteoporosis. 2010. Available from: http://www.nof.org/node/40. Accessed November 17, 2011.

7. Utian WH. Psychosocial and socioeconomic burden of vasomotor symptoms in menopause: a comprehensive review. Health Qual Life Outcomes. 2005;3:47.

8. Suckling J, Lethaby A, Kennedy R. Local oestrogen for vaginal atrophy in postmenopausal women. Cochrane Database Syst Rev. 2006;4: CD001500.

9. Swanson SG, Drosman S, Helmond FA, Stathopoulos VM. Tibolone for the treatment of moderate to severe vasomotor symptoms and genital atrophy in postmenopausal women: a multicenter, randomized, double-blind, placebo-controlled study. Menopause. 2006;13(6): 917-925.

10. North American Menopause Society. Management of osteoporosis in postmenopausal women: 2010 position statement of The North American Menopause Society. Menopause. 2010;17(1): $25-54$.

11. North American Menopause Society. Estrogen and progestogen use in postmenopausal women: 2010 position statement of The North American Menopause Society. Menopause. 2010;17(2): 242-255.

12. Voigt LF, Weiss NS, Chu J, Daling JR, McKnight B, van Belle G. Progestagen supplementation of exogenous oestrogens and risk of endometrial cancer. Lancet. 1991;338(8762):274-277.

13. Weiderpass E, Adami HO, Baron JA, et al. Risk of endometrial cancer following estrogen replacement with and without progestins. J Natl Cancer Inst. 1999;91(13):1131-1137.

14. Rossouw JE, Anderson GL, Prentice RL, et al. Risks and benefits of estrogen plus progestin in healthy postmenopausal women: principal results from the Women's Health Initiative randomized controlled trial. JAMA. 2002;288(3):321-333.

15. Rolnick SJ, Kopher RA, DeFor TA, Kelley ME. Hormone use and patient concerns after the findings of the Women's Health Initiative. Menopause. 2005;12(4):399-404.

16. Kharode Y, Bodine PV, Miller CP, Lyttle CR, Komm BS. The pairing of a selective estrogen receptor modulator, bazedoxifene, with conjugated estrogens as a new paradigm for the treatment of menopausal symptoms and osteoporosis prevention. Endocrinology. 2008; 149(12): 6084-6091.

17. Komm BS, Lyttle CR. Developing a SERM: stringent preclinical selection criteria leading to an acceptable candidate (WAY-140424) for clinical evaluation. Ann N Y Acad Sci. 2001;949:317-326.

18. Komm BS, Kharode YP, Bodine PV, Harris HA, Miller CP, Lyttle CR. Bazedoxifene acetate: a selective estrogen receptor modulator with improved selectivity. Endocrinology. 2005;146(9): 3999-4008.

19. Berrodin TJ, Chang KC, Komm BS, Freedman LP, Nagpal S. Differential biochemical and cellular actions of premarin estrogens: distinct pharmacology of bazedoxifene-conjugated estrogens combination. Mol Endocrinol. 2009;23:75-85.
20. Chang KCN, Wang Y, Bodine PV, Nagpal S, Komm BS. Gene expression profiling studies of three SERMs and their conjugated estrogen combinations in human breast cancer cells: insights into the unique antagonistic effects of bazedoxifene on conjugated estrogens. J Steroid Biochem Mol Biol. 2010;118(1-2):117-124.

21. Crabtree JS, Peano BJ, Zhang X, Komm BS, Winneker RC, Harris HA. Activity of three selective estrogen receptor modulators on hormonedependent responses in the mouse uterus and mammary gland. Mol Cell Endocrinol. 2008;287(1-2):40-46.

22. Peano BJ, Crabtree JS, Komm BS, Winneker RC, Harris HA. Effects of various selective estrogen receptor modulators with or without conjugated estrogens on mouse mammary gland. Endocrinology. 2009;150(4):1897-1903.

23. Komm BS, Vlasseros F, Samadfam R, Chouinard L, Smith SY. Skeletal effects of bazedoxifene paired with conjugated estrogens in ovariectomized rats. Bone. 2011;49(3):376-386.

24. Lobo RA, Pinkerton JV, Gass ML, et al. Evaluation of bazedoxifene/ conjugated estrogens for the treatment of menopausal symptoms and effects on metabolic parameters and overall safety profile. Fertil Steril. 2009;92(3): 1025-1038.

25. Archer DF, Lewis V, Carr BR, Olivier S, Pickar JH. Bazedoxifene/ conjugated estrogens (BZA/CE): incidence of uterine bleeding in postmenopausal women. Fertil Steril. 2009;92(3):1039-1044.

26. Lindsay R, Gallagher JC, Kagan R, Pickar JH, Constantine G. Efficacy of tissue-selective estrogen complex of bazedoxifene/conjugated estrogens for osteoporosis prevention in at-risk postmenopausal women. Fertil Steril. 2009;92(3):1045-1052.

27. Pickar JH, Yeh I-T, Bachmann G, Speroff L. Endometrial effects of a tissue selective estrogen complex containing bazedoxifene/ conjugated estrogens as a menopausal therapy. Fertil Steril. 2009;92(3): $1018-1024$.

28. Pinkerton JV, Utian WH, Constantine GD, Olivier S, Pickar JH. Relief of vasomotor symptoms with the tissue-selective estrogen complex containing bazedoxifene/conjugated estrogens: a randomized, controlled trial. Menopause. 2009;16(6):1116-1124.

29. Kagan R, Williams RS, Pan K, Mirkin S, Pickar JH. A randomized, placebo- and active-controlled trial of bazedoxifene/conjugated estrogens for treatment of moderate to severe vulvar/vaginal atrophy in postmenopausal women. Menopause. 2010;17(2):281-289.

30. Dreyer P, Vieira JG. Bone turnover assessment: a good surrogate marker? Arq Bras Endocrinol Metabol. 2010;54(2):99-105.

31. Mandelson MT, Oestreicher N, Porter PL, et al. Breast density as a predictor of mammographic detection: comparison of interval- and screen-detected cancers. J Natl Cancer Inst. 2000;92(13):1081-1087.

32. McCormack VA, dos Santos Silva I. Breast density and parenchymal patterns as markers of breast cancer risk: a meta-analysis. Cancer Epidemiol Biomarkers Prev. 2006;15(6):1159-1169.

33. Harvey JA, Pinkerton JV, Baracat EC, Shi H, Mirkin S, Chines AA. Evaluation of changes in mammographic breast density associated with bazedoxifene/conjugated estrogens in postmenopausal women. Endocr Rev. 2011;32(3):P1-P79.

34. Pinkerton JA, Constantine GD, Komm BS, Yu H, Pickar JH. Breast effects of bazedoxifene/conjugated estrogens in a randomized, controlled trial of postmenopausal women. Poster presented at: The 19th Annual Meeting of the North American Menopause Society; September 24-27, 2008; Lake Buena Vista, FL, USA; 2008. Abstract P-46.

35. Pinkerton JV, Taylor H, Pan K, Chines A, Mirkin S. Breast parameters with bazedoxifene/conjugated estrogens in randomized, controlled trials of postmenopausal women. Menopause. 2010;17(6):1221-1222.

36. Spencer CP, Godsland IF, Stevenson JC. Is there a menopausal metabolic syndrome? Gynecol Endocrinol. 1997;11(5): $341-355$.

37. Kronenberg F. Hot flashes: phenomenology, quality of life, and search for treatment options. Exp Gerontol. 1994;29(3-4):319-336.

38. Pinkerton JV, Chines AA, Racketa J, Mirkin S. Bazedoxifene/conjugated estrogens (BZA/CE): effect on sleep parameters in postmenopausal women. Menopause. 2010;17(6):1237-1238. 
39. Utian W, Yu H, Bobula J, Mirkin S, Olivier S, Pickar JH. Bazedoxifene/ conjugated estrogens and quality of life in postmenopausal women. Maturitas. 2009;63(4):329-335.

40. Pinkerton JV, Chines AA, Racketa J, Mirkin S. Menopause-related quality of life and satisfaction in postmenopausal women treated with bazedoxifene/conjugated estrogens (BZA/CE). Menopause. 2010;17(6):1219.

41. Bachmann G, Bobula J, Mirkin S. Effects of bazedoxifene/conjugated estrogens on quality of life in postmenopausal women with symptoms of vulvar/vaginal atrophy. Climacteric. 2010;13(2):132-140.

42. Topal NB, Ayhan S, Topal U, Bilgin T. Effects of hormone replacement therapy regimens on mammographic breast density: the role of progestins. J Obstet Gynaecol Res. 2006;32(3):305-308.

43. Martin LJ, Minkin S, Boyd NF. Hormone therapy, mammographic density, and breast cancer risk. Maturitas. 2009;64(1):20-26.

44. Freedman M, San Martin J, O'Gorman J, et al. Digitized mammography: a clinical trial of postmenopausal women randomly assigned to receive raloxifene, estrogen, or placebo. J Natl Cancer Inst. 2001;93(1): 51-56.

45. Barnabei VM, Cochrane BB, Aragaki AK, et al. Menopausal symptoms and treatment-related effects of estrogen and progestin in the Women's Health Initiative. Obstet Gynecol. 2005;105:1063-1073.

46. Lobo RA, Bush T, Carr BR, Pickar JH. Effects of lower doses of conjugated equine estrogens and medroxyprogesterone acetate on plasma lipids and lipoproteins, coagulation factors, and carbohydrate metabolism. Fertil Steril. 2001;76(1):13-24.
47. Hays J, Ockene JK, Brunner RL, et al. Effects of estrogen plus progestin on health-related quality of life. NEngl J Med. 2003;348(19): 1839-1854.

48. Brunner RL, Gass M, Aragaki A, et al. Effects of conjugated equine estrogen on health-related quality of life in postmenopausal women with hysterectomy: results from the Women's Health Initiative Randomized Clinical Trial. Arch Intern Med. 2005;165(17):1976-1986.

49. Polo-Kantola P, Erkkola R, Helenius H, Irjala K, Polo O. When does estrogen replacement therapy improve sleep quality? Am J Obstet Gynecol. 1998;178(5):1002-1009.

50. Barnabei VM, Grady D, Stovall DW, et al. Menopausal symptoms in older women and the effects of treatment with hormone therapy. Obstet Gynecol. 2002;100(6):1209-1218.

51. Gelfand MM, Moreau M, Ayotte NJ, Hilditch JR, Wong BA, Lau CY. Clinical assessment and quality of life of postmenopausal women treated with a new intermittent progestogen combination hormone replacement therapy: a placebo-controlled study. Menopause. 2003;10(1):29-36.

52. Hlatky MA, Boothroyd D, Vittinghoff E, Sharp P, Whooley MA. Quality-of-life and depressive symptoms in postmenopausal women after receiving hormone therapy: results from the Heart and Estrogen/ Progestin Replacement Study (HERS) trial. JAMA. 2002;287(5): 591-597.

53. Haines CJ, Yim SF, Chung TK, et al. A prospective, randomized, placebo-controlled study of the dose effect of oral oestradiol on menopausal symptoms, psychological well being, and quality of life in postmenopausal Chinese women. Maturitas. 2003;44(3):207-214.
International Journal of Women's Health

\section{Publish your work in this journal}

The International Journal of Women's Health is an international, peerreviewed open-access journal publishing original research, reports, reviews and commentaries on all aspects of women's healthcare including gynecology, obstetrics, and breast cancer. Subject areas include: Chronic conditions (migraine headaches, arthritis, osteoporosis);

\section{Dovepress}

Endocrine and autoimmune syndromes; Sexual and reproductive health; Psychological and psychosocial conditions. The manuscript management system is completely online and includes a very quick and fair peer-review system. Visit http://www.dovepress.com/ testimonials.php to read real quotes from published authors. 